\title{
Extemporaneous Intervention to Construct a Financial Education History
}

\author{
Jéssica Ignácio de Souza ${ }^{\mathrm{a}}$ \\ Cláudia Regina Flores@ $\circledast^{\mathrm{b}}$ \\ a Universidade Federal de Santa Catarina, Programa de Pós-Graduação em Educação Científica e Tecnológica, \\ Florianópolis, SC, Brasil. \\ ${ }^{\text {b } U n i v e r s i d a d e ~ F e d e r a l ~ d e ~ S a n t a ~ C a t a r i n a, ~ P r o g r a m a ~ d e ~ P o ́ s-G r a d u a c ̧ a ̃ o ~ e m ~ E d u c a c ̧ a ̃ o ~ C i e n t i ́ f i c a ~ e ~ T e c n o l o ́ g i c a, ~}$ \\ Departamento de Metodologia de Ensino, Florianópolis, SC, Brasil. \\ Received for publication on 27 Apr. 2020. Accepted after review on 5 Oct. 2020 \\ Designated editor: Claudia Lisete Oliveira Groenwald
}

\begin{abstract}
Background: The inclusion of financial education in the mathematics curriculum of the basic Brazilian education, both in elementary and high school, has been the subject of discussion in recent academic research, as well as in propositional and normative documents, such as the National Common Curricular Base (BNCC). Objective: This article aims to present the theoretical and methodological perspective used to build a history of financial education, which is part of the mathematics curriculum taught in Brazilian public schools. Design: For this, we use conceptual tools proposed by Michel Foucault, inspired by Nietzsche's writings, such as the concepts of Herkunft (provenance) and Entestehung (emergence). Scenario and Participants: We rely on the writings of Michel Foucault, studying the teaching of mathematics, in the specificity of this theme, with contributions from philosophical and historical writing, also inspiring us in the concepts of genealogy, union between philosophy and history, according to Nietzsche. Data collection and analysis: The textbooks were collected from the Museu da Escola Catarinense, while the academic works were retrieved from CAPES data bank for the qualitative analysis. Results: Hence, five methodological precautions for the analysis of power and the constitution of an object called financial education are described, namely: the financial education theme comes from a dispersion of practices, and not from an origin; we are interested in the power relations that are engendered, and that forge a financial education; the subjects are agents and effects of utterances forming a discursive network on economics; the analysis focuses on the mechanisms, techniques, and tactics, not on the centre of the power; financial education is the topic that results from the confrontation of power relations. Conclusions: With this research, we intended to make an extemporaneous intervention so that it is possible for teachers to reflect and problematise their practice in the face of this new role they are attributed.
\end{abstract}

Keywords: financial education; extemporaneous intervention; financial education history.

Corresponding Author: Jéssica Ignácio de Souza. Email: jessica_isouza@hotmail.com 


\title{
Intervenção Extemporânea para Construção de uma História da Educação Financeira
}

\begin{abstract}
RESUMO
Contexto: A inclusão da educação financeira no currículo de matemática da educação básica brasileira, tanto no ensino fundamental quanto no médio, tem sido objeto de discussão em pesquisas acadêmicas recentes, bem como em documentos propositivos e normativos, como a Base Curricular Comum Nacional ( BNCC). Objetivo: este artigo tem como objetivo apresentar a perspectiva teórico-metodológica utilizada para a construção de uma história da educação financeira, que faz parte do currículo de matemática ministrado nas escolas públicas brasileiras. Design: Para isso, utilizamos ferramentas conceituais propostas por Michel Foucault, inspiradas nos escritos de Nietzsche, como os conceitos de Herkunft (proveniência) e Entestehung (emergência). Cenário e Participantes: Apoiamo-nos nos escritos de Michel Foucault, estudando o ensino da matemática, na especificidade desse tema, com aportes da escrita filosófica e histórica, nos inspirando, ainda, nos conceitos da genealogia, união entre filosofia e história, segundo Nietzsche. Coleta e análise de dados: Os livros didáticos foram coletados no Museu da Escola Catarinense, enquanto os trabalhos acadêmicos foram recuperados do banco de dados da CAPES para análise qualitativa. Resultados: Descrevem-se, assim, cinco precauções metodológicas para a análise do poder e da constituição de um objeto denominado educação financeira, a saber: o tema educação financeira surge de uma dispersão de práticas, e não de uma origem; interessa-nos as relações de poder que se engendram e que forjam uma educação financeira; os sujeitos são agentes e efeitos de enunciados formando uma rede discursiva sobre economia; a análise se concentra nos mecanismos, técnicas e táticas, não no centro do poder; educação financeira é o tema que resulta do enfrentamento das relações de poder. Conclusões: Com esta pesquisa, pretendeu-se fazer uma intervenção extemporânea para que seja possível aos professores refletir e problematizar a sua prática face a este novo papel que lhes é atribuído.
\end{abstract}

Palavras-chave: educação financeira; intervenção extemporânea; história da educação financeira.

\section{INTRODUCTION}

The inclusion of financial education in the mathematics curriculum of the basic Brazilian education, both in elementary and high school, has been the subject of discussion in recent academic research (Schneider, 2008; Kern, 2009; Novaes, 2009; Campos, 2012; Reis, 2013; Alves, 2014; Oliveira, 2014), as well as in propositional and normative documents, such as the National Common Curricular Base (BNCC). The aim of the thesis ${ }^{1}$ from which we wrote this article is to build a history of something called financial education. This something permeates various contents of the mathematics curriculum, not being restricted to the so-called financial mathematics, that is, to the study of concepts such as rate, interest, amount, etc. This something also permeates other disciplines of the school curriculum, crosses and is intertwined with the life and formation of a neoliberal subject. To refer to this something, we chose to call it a theme, and study the discourses that form and sustain its materiality in the mathematics curriculum.

${ }^{1}$ Thesis developed by the first author, in the Scientific and Technological Education Program, PPGECT-UFSC- Brazil, under the supervision of the second author. 
For mathematics as school subject, the concepts of financial mathematics are indicated in the National Curriculum Parameters (PCN) of elementary education (Brazil, 1998). The subject is therefore proposed to be dealt with in the Numbers and Operations axis when addressing the themes of proportionality, notion of variables and unknowns and simplifications of algebraic expressions, which, according to the document, provide connection with the transversal theme "Work and Consumption". A decade afterwards, there was an attempt to make the financial education mandatory in the mathematics curriculum of basic education through bill n. 171 (Brasil, 2009). The project went through the National Congress, aiming to change the wording of the LDB (Brasil, 1996) with the addition of the following in art. 26, paragraph 7: "the theme of financial education is part of the mathematics curriculum." However, the Project was rejected in 2012 with the rationale that curricula themes should not be enforced by law.

In 2010, the National Strategy for Financial Education (ENEF) was created by Federal Decree $n^{0} 7.397$ (Brasil, 2010). This action is considered a permanent State policy and, according to the website ${ }^{2}$, “(...) its objective is to contribute to the strengthening of citizenship by providing and supporting actions that help the population to make more autonomous and conscious financial decisions." In the second version of the document for the National Common Curricular Base (BNCC), it was presented as the first of the five Special Themes ${ }^{3}$ "economy, financial education and sustainability" (Brasil, 2016). ENEF was cited as one of the reasons for the inclusion of the financial theme in the BNCC. This policy can reach school education not only through BNCC, but also through the production of didactic materials and projects for the training of public-school teachers, promoted by ENEF.

The commercial and financial issues were presented in the second version of the BNCC as part of the mathematics teaching in all stages of teaching in Brazilian basic education. In the 4th and 5th grades of elementary school and in the final years of elementary school, these issues should be related to the teaching of percentage. For high school, the document states that " (...) students are expected to solve problems involving percentages in real financial situations, payments by credit card, financing, amortization and the price table, including the use of calculators or electronic spreadsheets" (Brasil, 2016, p. 573).

The final document of BNCC for early childhood education and elementary education was approved by the Ministry of Education in December 2017. The guidelines are that in the initial years, in the fourth grade, the thematic unit "Quantities and Measures" should address problems using the Brazilian monetary system. Following, in the final years, students must master, in addition to other issues, how to calculate percentage, percentage of percentage, interest, rebates and additions.

Another aspect to be considered in this thematic unit [Number] is the study of basic concepts of economics and finance, aiming at the financial education of students.

\footnotetext{
${ }^{2}$ Available at: $<$ http://www.vidaedinheiro.gov.br/quemsomos/>. Accessed on 9 Feb. 2018.

${ }^{3}$ The five special themes contained in the second version of the BNCC are: Economy, financial education, and sustainability; Indigenous and African cultures; Digital cultures and computing; Human rights and citizenship; and Environmental education (Brasil, 2016).
} 
Thus, subjects such as interest rates, inflation, financial investments (return and liquidity of an investment) and taxes can be discussed. This thematic unit favours an interdisciplinary study involving the cultural, social, political, and psychological -in addition to the economic- dimensions, on the issues of consumption, work, and money. (Brasil, 2017, p. 267, emphasis added)

The final document, addressing high school, was approved in 2018, and is presented in less detail. It indicates that contemporary themes should be incorporated into the curricula, including education for consumption and financial education (Brasil, 2018). Financial Mathematics is indicated as a skill of the specific competences $3^{4}$ and $5^{5}$.

Some of the skills indicated for the thematic unit Numbers and Algebra in high school are presented as follows:

Interpret economic situations critically; interpret rates and indexes of an economic nature (such as inflation rates).

Apply mathematical concepts in planning, executing and analysing actions involving both the use of applications and the creation of spreadsheets (for family budget control, simple and compound interest calculation simulators, among others), to make decisions. (Brasil, 2018, p. 543)

Interpret and compare situations involving simple interest with those involving compound interest, through graphical representations or spreadsheet analysis, highlighting the linear or exponential growth of each case.

Solve and elaborate problems with exponential and logarithmic functions in which it is necessary to understand and interpret the variation of the quantities involved, in contexts such as Financial Mathematics, among others. (Brasil, 2018, p. 544)

Despite the similarity of the indications of the PCNs and the BNCC for the approach of financial mathematics concepts regarding the thematic unit and the relationship that must be made with other contents, in addition to those specific to financial mathematics, such as percentage and proportionality, financial education was not mentioned in the PCNs, a movement that gained space in the BNCC. This apparent subtle difference shows a new appeal to the math teacher, who must not only teach the calculations of financial mathematics, but more than that, needs to educate students financially for consumption and work.

\footnotetext{
4 "Use mathematical strategies, concepts and procedures in their fields - Arithmetic, Algebra, Quantities and Measures, Geometry, Probability and Statistics - to interpret, build models and solve problems in different contexts, analysing the plausibility of the results and the adequacy of the solutions proposals, in order to build consistent arguments" (Brasil, 2018, p. 527).

5 "Investigate and establish conjectures regarding different mathematical concepts and properties, using resources and strategies such as observing patterns, experiments and digital technologies, identifying the need, or not, for an increasingly formal demonstration in the validation of these conjectures" (Brasil, 2018, p. 532).
} 
In line with this assertion, Vargas (2012, p. 109-110) states that there is a "[ [... shift from Financial Mathematics (order of teaching) to Financial Education (order of education)" and that the school institution is "[...] being called by the State to educate financially and not simply teach Financial Mathematics".

We start, then, from this current problem, aiming to carry out an analysis on the financial education that took shape in school mathematics, that is, an analysis of which statements lead the calculation techniques, the knowledge about saving, profit and invest to become a theme (financial education) in mathematics teaching. To think and build a history of this theme, we rely on Michel Foucault's writings, which means studying the teaching of mathematics in the specificity of the theme, with contributions from philosophical and historical writing. To avoid the dangers of excessive scientificism and data when it comes to history, that is, the search for evidence of a certain origin and evolution of an object, as Nietzsche (2014) warns, we are inspired by the concepts of genealogy, the union between philosophy and history.

In this article, we present some of the conceptual tools that are operated to build a history of financial education, while showing the theoretical and methodological positions adopted in the specific case of our object of research.

\section{AN EMERGENCE ORIGIN, A PROVENANCE ORIGIN}

Foucault elaborates his genealogical procedure based on a reading of the Nietzschean genealogy, the main displacement of which, according to Ribeiro (2018), is the replacement of the body as an instinct by the subject as an empty function through which history is made. In Genealogy of Morals, Nietzsche asks: "under what conditions did man devise these value judgments 'good' and 'evil'? And what value do they themselves possess?" (Nietzsche, 2009, p. 9), and its initial construction shows a confrontational scene, an ongoing struggle against resentment, that is, there is no empty scene, there is an instinctual domain at play. However, Ribeiro (2018) warns, it is not a matter of saying that Foucault was wrong about this aspect of the Nietzschean genealogy, but that the originality of the philosopher's genealogical research lies there. In any case, the discussion about origin is crucial in both Nietzsche's and Foucault's history making.

With Foucault, genealogical research is presented with three approaches: strategic opposition to research of origin; body as an interstice, a space that emerges from what one fights for; field of forces as a space for confrontation and empowerment of rules, detailed description of the discourses (Ribeiro, 2018). This means to consider the emergence and the provenance of the event, which, while not being the aim of this article, will be dealt with in more detail and in a more articulated manner during the general development of our research.

For now, it is worth saying that taking into account the genealogical tools for historical writing means opposing the research of origin in the sense of the starting point of an action or object that has continuity and evolution over time, and, instead, 
considering the "conditions of possibilities that are external to the very knowledges, or rather, which, immanent to them - since it is not a question of considering them as an effect or a result - place them as elements of a device of an essentially political nature" (Machado, 2006, p. 167).

In this specific study, it does not mean showing that the financial education sustained today in documents providing suggestions to the curriculum, in academic research and in mathematics textbooks is something from the past that is still alive. It is about maintaining the past in the dispersion of events that were a condition, for the possibility of forming what we have today as financial education. It is also seeing how the constitution of a type of subject occurs in this historical plot, moving away from the need to refer to a subject that constitutes the object.

It means identifying dispersions, reconstituting the discursive threads that form the web that enables the emergence of a knowledge, that is, showing the bundle of relationships that is established in the dispersion of surrounding events that form and sustain it. For that, genealogy requires patience and many materials accumulated, tarrying over the details of knowledge.

Hence, for genealogy, an indispensable tarrying: to mark the singularity of events, far from any monotonous purpose; to stalk them there where they were least expected and in what is considered to have no history - feelings, love, conscience, instincts; to apprehend their return not to trace the slow curve of an evolution, but to rediscover the different scenes where they played different roles. (Foucault, 2017, p. 55, emphasis added)

These different scenes are what we call dispersion, borrowing Michel Foucault's term. Therefore, it is not about presenting a certain origin of financial education in school mathematics or in the school curriculum. It is not a matter of going to the past and reconstructing its evolution and showing that here and there, in textbooks and laws, financial education content appears and evolves to the present day. It is a question of considering all of the sources mentioned - and also others - in order to rediscover the different scenes where the elements that make up the condition for the possibility of a financial education to be in school mathematics are found.

In pursuing the construction of a history based on the concept of genealogy, we withdraw from research that seeks a particular origin. Foucault explains why Nietzsche refuses the research of the origin of the Ursprung type.

Because, first of all, in this sense, research strives to gather the exact essence of the thing, its purest possibility, its identity carefully collated within itself, its immobile form and previous to all that is external, accidental or successive. To search for such an origin is to try to rediscover "what was immediately", the "same" of an exactly adequate image of oneself; it is to take as incidental all the adventures that 
could have happened, all the cunning, all the disguises; it is to want to remove all the masks to finally reveal a first identity. (Foucault, 2017, p. 58)

In other words, one does not look for an essence that is hidden behind things. We do not seek, when building a history of financial education, to define or represent what is essentially the financial education that appears in the mathematics curriculum, we do not ask what is behind this presence, after all, what is "behind" things is "something entirely different: not their essential and undated secret, but the secret that they are without essence, or that their essence was built piece by piece from figures that were foreign to it" (Foucault, 2017, p. 58). It is worth noting that it does not mean looking for what are considered beginnings and declaring them as false or refusable but seeing Ursprung as a strategic way of admitting another beginning, another history (Ribeiro, 2018). In this way, we seek an origin of a financial education that is presented today in the school mathematics curriculum, but an origin in the sense of provenance and in the sense of emergence. We explain: Foucault presents other terms used by Nietzsche that are usually translated as origin, but have their own articulations: Herkunft (provenance) and Entestehung (emergence).

Herkunft is the research of provenance: "The research of provenance is not foundational, quite the contrary: it disturbs what was considered immobile, it fragments what was thought unified; it shows the heterogeneity of what was imagined consistent with itself" (Foucault, 2017, p. 63-64). It is not thinking about evolution or destiny, but, on the contrary, maintaining what happened in the dispersion. A genealogical analysis that presents an origin as provenance is "[...] at the point of articulation of the body with history. It must show the body entirely marked by history and history ruining the body" (Ibidem, p. 65). The body is an interstice, an empty space that sustains and is an effect of events, which means to consider and to show the ${ }^{6}$ multiple and heterogeneous events present in the constitution of the subject and their identities. It means asking, in the field of studies that proposes to think about the mathematics that is taught at school, what kind of subject is constituted in the historical plot, so that certain contents are brought to the school curriculum. In this sense, we consider financial education a school theme that is not restricted to the processes of teaching and learning, but also a technology of the neoliberal governmental rationality, which seeks to form a homo economicus required for the good operation of the economy.

Foucault speaks of homo economicus to refer to the economic subject whose characteristics are updated according to the economy of each historical period. Homo economicus in the 18th century was one that, from the point of view of a governmental theory, should not be touched, that is, it was the subject of laissez-

\footnotetext{
6 "It is necessary to understand by event not a decision, a treaty, a kingdom, or a battle, but the relationship of forces that is reversed, a confiscated power, a vocabulary retaken and turned against its users, a denomination that is weakened, distended, poisoned, and other that makes its entrance, masked. The forces that are at stake in history do not obey either a destination or mechanics, but the chance of the struggle" (Foucault, 2017, p. 73).
} 
faire. In the neoliberal economic analysis, this notion was modified and the homo economicus became

one who accepts reality or responds systematically to systematic changes that are artificially introduced into the environment. Homo economicus is one that is eminently governable. As an intangible partner of laissez-faire, homo economicus now appears as the correlative of a possibility of governance that will act on the environment and systematically modify the variables of the environment. (Foucault, 2018, p. 337)

From this, for example, we made a methodological analysis of mathematics textbooks from other historical moments that presented contents related to financial mathematics, to understand whether a type of financial education was present or not. The selection of books took place from reading the summaries of the collection of the Museu da Escola Catarinense - located in the capital of Santa Catarina, Florianópolis (Brazil) - of which we highlight two with inscriptions of types of education for economy, in order to problematise the theme, namely: "Matemática para a Terceira Série Ginasial" (Sangiorgi, 1954) and "Curso de Matemática 2ªno" (Roxo, Thiré, \& Souza, 1940).

The first book cited is divided into Reasons and Proportions and Geometry, and topics in financial mathematics are inserted in the part of the book that deals with Reasons and Proportions. The emphasis on explaining the formulas, the technical definition of the concepts, as well as the exercises proposed (Figure 1) indicate a teaching of financial mathematics not focused on the financial education that is presented today. That is to say, the objective is not to make individuals aware of financial decision-making, but rather make them learn calculation rules. In the exercise list related to the subject, there is an emphasis on the application of formulas based on the data presented in the question, without giving space for a thinking beyond this procedure.

Figure 1 shows a list of financial mathematics exercises in a mathematics textbook dated 1954, 


\section{Figure 1}

List of financial mathematics exercises in a 1954 mathematics textbook (Sangiorgi, 1954)

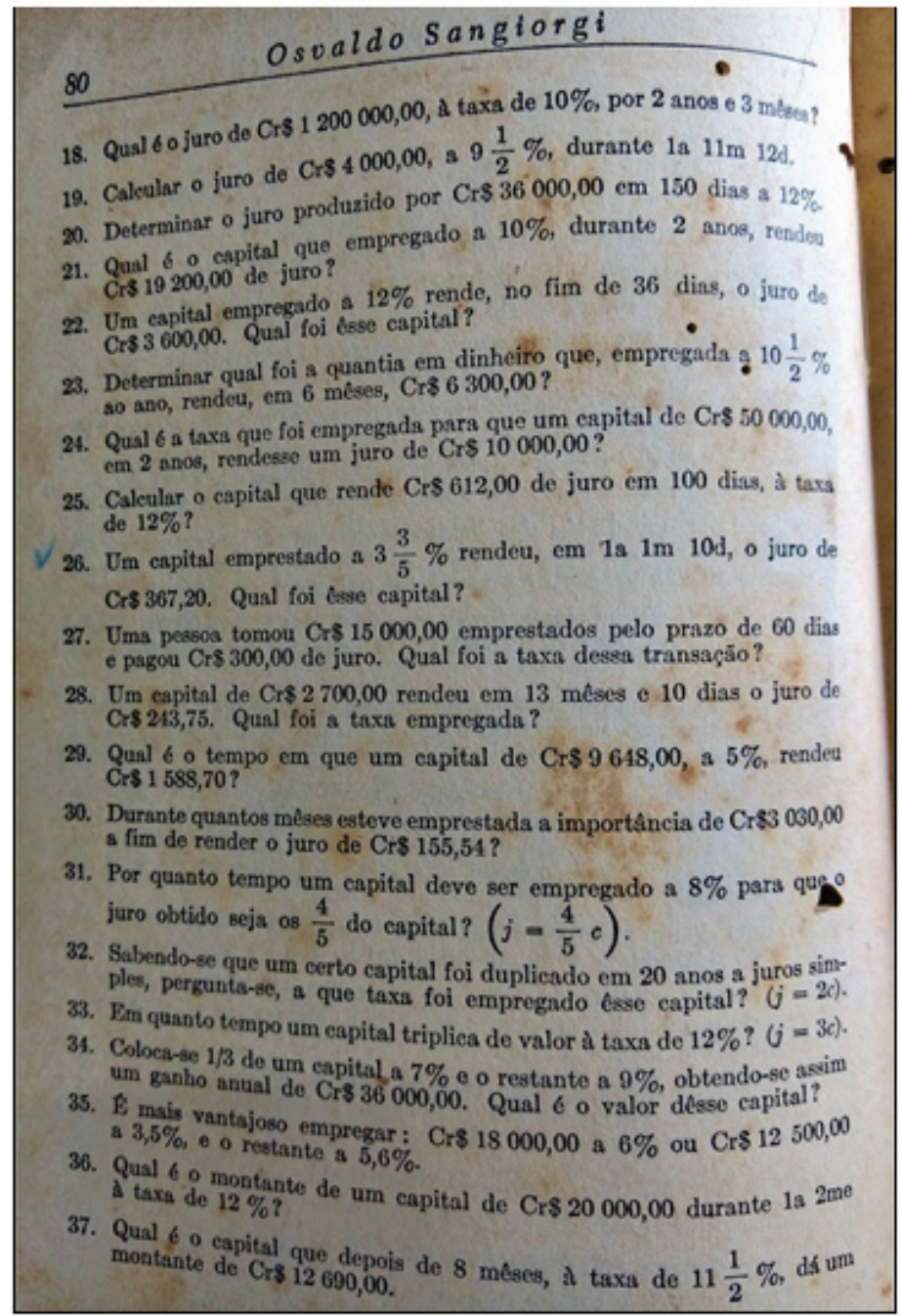

The work with financial concepts and their formulas allows us to infer about the inclusion of a discursive practice related to financial mathematics in the school textbook, since the mid-1950s, for whose society - or part of it, taking into account that only a portion of the Brazilian population had access to high school - the financial education was already needed. Therefore, a guideline to conscious thinking for financial decisions is not inscribed in this book, as this element (a financial teaching in mathematics) of the web forming the homo economicus of the time is different from what we have today. 
The second book, from 1940, approaches not only calculations, formulas, and definitions, but also more reflective texts on economic situations. The starting chapter, entitled "Noções preliminares" (Preliminary Notions), on simple interests, addresses commercial, business and factory work by presenting as an example which elements would be necessary for a brick factory to be established and produce wealth (Figure 2).

Figure 2 shows texts on financial concepts in a 1940 mathematics textbook.

Figure 2

Topics on financial mathematics in middle school (Roxo, Thiré, \& Souza, 1940)

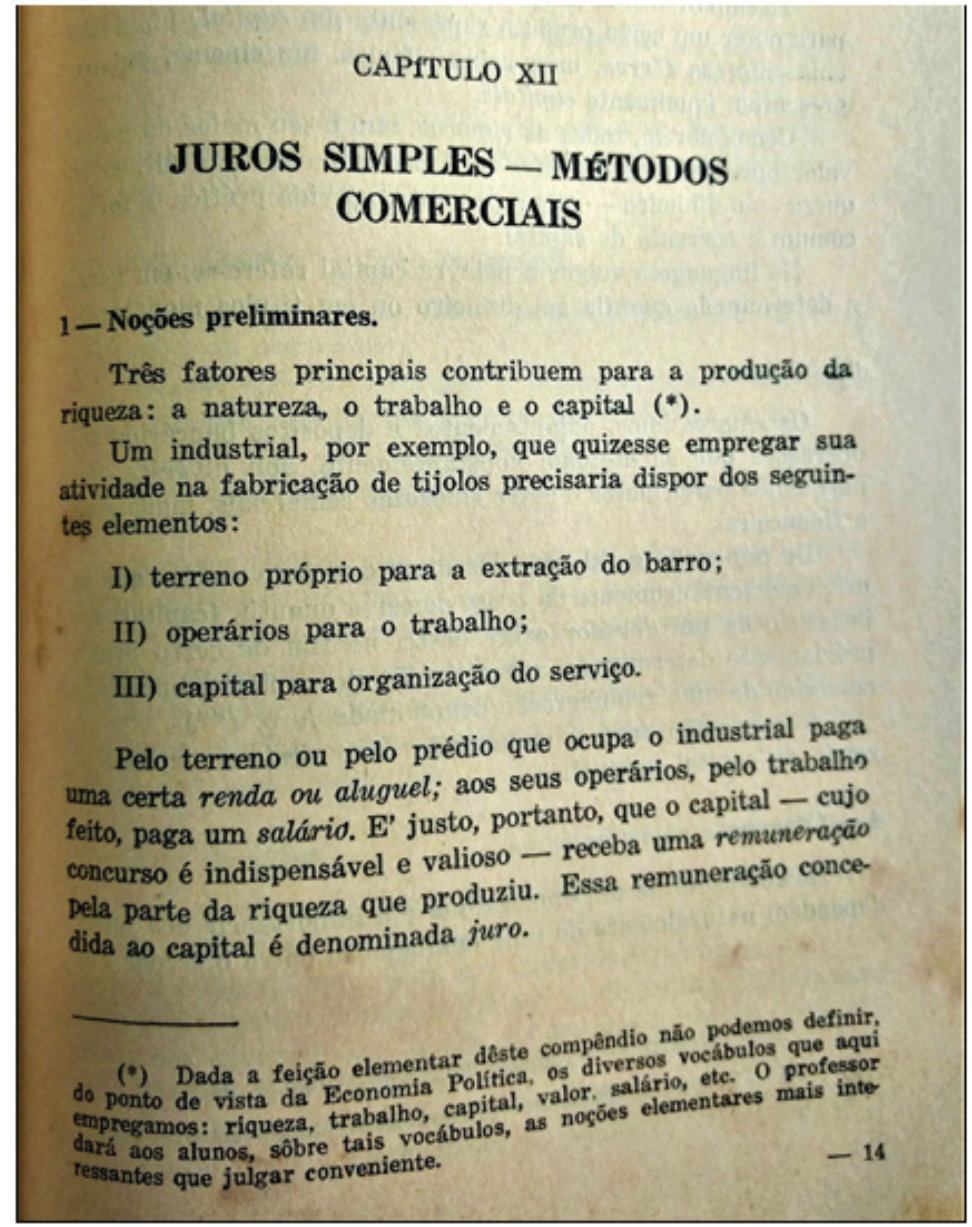

Let us observe that, when discussing the influences on the determination of interest rates, the authors state that a company that offers little security will obtain loans at high 
rates, while companies that will invest the bank's borrowed capital on "guaranteed success" businesses, will get lower rates. In other words, the focus in all texts is to present discussions on financial issues related to business, commercial and manufacturing activities.

Therefore, in the textbooks analysed, there is no reference to consumption, to the consumer, but to a homo economicus as the other partner in the exchange process: the factory entrepreneur. A mathematics is inscribed in the book to form the man of the company, but the one connected to the factory and commerce, rather than one connected to the company itself in terms of strategies and tactics for conscious consumption, as required today. This can be explained by the "late" arrival, in 1980, of the biopolitical State in Brazil.

Therefore, we can infer that in the mid-1940s and 1950s the mathematics proposed in the textbooks was geared towards the formation of the entrepreneurial subject of the factory and commerce, as opposed to what is presently wanted by a formation of ways of behaving in the economic field for neoliberalism, that is, a conscious consumer who accepts and responds to changes of the environment.

The other term that is commonly translated as origin, but that presents other problematizations, Entestehung, refers to the emergence, which is "the entry of forces on the scene; it is their eruption, the leap from the wings to the centre stage, each in its youth and strength" (Foucault, 2017, p. 67). However, we must be careful not to think of this leap from the wings to the stage as if everything had been long previously prepared and planned, on the contrary, "it is the scene where forces take risks and confront each other, in which they can triumph or be confiscated" (Ibidem, p. 79). The research of the emergence origin deals with events regarding the power relations involved in them, it seeks to see the strategies and tactics that are engendered considering the state of forces of the moment. It is about showing how the discourses that forge rules for the space of confrontation emerge and how the forces operate.

To this end, we carried out a survey on the portal of theses and dissertations of the Coordination for the Improvement of Higher Education Personnel (CAPES), Brazil, aiming to, beyond a production balance with numerical and statistical data, carry out an analysis of the statements that form and support the idea that financial education should be present in the school mathematics curriculum. Brazilian theses and dissertations on financial education and financial mathematics in basic education present, recurrently, the discursive assumption that it is the need for a work with mathematics that is linked to the students' daily lives, so that they adapt to reality ${ }^{7}$ (Schneider, 2008; Novaes, 2009; Reis, 2013; Oliveira, 2014).

Duarte (2009), for example, in her thesis, described and analysed the discursive plots of the statement about the importance of teaching mathematics geared to the students' reality. According to the author, both in the 20th century and in contemporary times, this

${ }^{7}$ It is worth mentioning that other statements are evidenced in the thesis, however, we will not address them this article due to the page limits of this type of production. 
statement is linked to the idea that such an action would make the school more attractive and arise the students' interest in school mathematics. In addition, it would be intertwined with the purpose of teaching to have social implications in the sense of promoting the maintenance and stability of the social order of the 20th century, which has changed in contemporary times to make individuals have a critical conscience with a view to the social change of the world.

Furthermore, from the theses and dissertations selected for this research, a state of forces is perceived as one of the ways that form, support and justify today the theme of financial education along with the mathematical content, which is the dual maintenance of socioeconomic order and critical awareness, that is, the existence of works that defend the insertion of this theme in the curriculum for the good operation of the existing economy and social order, with regard to the education of subjects on how to consume financial products, how to invest and how to make payment through different means (Campos, 2012; Schneider, 2008; Oliveira, 2014). Also, the existence of a work that defends the approach of financial education with a view to the critical awareness of the subjects (Reis, 2013).

With genealogy, an origin is sought not to show when, in the past, and through which constituent subject, knowledge appears (or a theme in the school curriculum), but the origin in the sense of provenance and emergence. In other words, to show the dispersion of the elements that mark the articulation of the body with history and the eruption of the event ${ }^{8}$ and the entire network of power that is engendered in it. It is to suspend the Ursprung origin and its effect of truth and to consider the body as "a space in which something emerges for which one fights" and to show the field that composes the entry of the forces on the scene.

The examples of procedures adopted in the specific case of research on financial education in the mathematics curriculum of Brazilian schools, such as the analysis of mathematics textbooks and theses and dissertations on the subject, were presented separately in the exposition of the text, however, it is worth mentioning that the concepts of Herkunft (provenance) and Entestehung (emergence) are taken into account in the analysis of the entire documentation corpus of the research, not least because we do not consider it possible to separate them analytically.

As the research of the origin in the way we propose suggests the consideration of power relations, we highlight five methodological precautions for the analysis of power.

\footnotetext{
8 "It is necessary to understand by event not a decision, a treaty, a kingdom, or a battle, but the relationship of forces that is reversed, a confiscated power, a vocabulary retaken and turned against its users, a denomination that is weakened, distended, poisoned, and another that makes masked its entrance. The forces that are at stake in history do not obey either a destination or mechanics, but the chance of the struggle" (Foucault, 2017, p. 73).
} 


\section{THE FIVE METHODOLOGICAL PRECAUTIONS}

Foucault (2017) presents five methodological precautions in relation to the analysis of power in law: capturing power in its last ramifications; studying the power on its external face; analysing power as something that circulates; doing an upward analysis of power; and considering that what is formed at the base are real instruments of formation and accumulation of knowledge.

The first precaution refers to not considering power only in its regulatory forms at its centre,

On the contrary, it is a question of capturing power in its extremities, in its last ramifications, where it becomes capillary; capturing power in its more regional and local forms and institutions, especially at the point where, going beyond the rules of law that organise and delimit it, it extends, penetrates institutions, embodies techniques and equips itself with material intervention, possibly violent, instruments. (Foucault, 2017, p. 282)

Foucault here is exemplifying methodological precautions for an analysis of law that considers power not as central, but, rather, penetrating the details of society.

It can be questioned, then, in what sense this all would be related to a historical construction, the object of which is financial education. We refer here to tools, or precautions, of a genealogical methodology that we want to pursue, not in the sense of a methodological prescription or step-by-step, even because, by doing so, we would be going in the opposite direction to the very theoretical framework, but in the sense of inspiring thoughts in relation to the mechanism of power that is exercised and forms the object that we propose to study. In the case of the first precaution, for the analysis of the formation of a financial education in school mathematics, we take into account that power is not found exclusively in the curricular legislation, which would come from a higher and external order, proposing this theme for teaching basic education mathematics classes, but it is also found in school practices, in institutions that produce research on the subject, in textbooks, in the economic mechanisms of society, that is, in a dispersion of elements and practices that end up forming the object which is being spoken of.

We did not analyse the curriculum in isolation, we did not look into official historical documents for an essential origin, with date and place, but we started from them to problematise the whole bundle of power relations, the entire confrontation of forces that have given the possibility of insertion of a theme in the math curriculum taught at school. The statements identified in the academic research that we examined and the subjection of types of homo economicus are, for example, embodiments of techniques, penetrated and branched forms of power. 
The second precaution presented by Foucault is not to approach power from the inside, but rather

[...] studying power on its external face, where it is directly and immediately related to what we can provisionally call its object, its target or field of application, that is, where it is implanted and produces real effects. So don't ask why some want to dominate, what they are looking for and what their overall strategy is, but how things work at the level of the subjection process or the continuous and uninterrupted processes that subject bodies, direct gestures, govern behaviours etc. (Foucault, 2017, p. 283)

It means not to analyse power in the order of intention or decision. It is not a question of asking: what is the intention of including financial education in the curriculum? What do they want with this financial education? But rather: what power relations are engendered in the formation of financial education? How do those relationships govern behaviours and direct gestures and materialize in the formation of a certain subject? Analysing financial education as a field of application of power that produces real effects for a neoliberal subjection.

For this, we chose to study also current mathematics textbooks that include financial education as a theme, which shows us a subject's preparation for work as an economic behaviour, of a machine/flow subject; and also training for conscious consumption, but consciously active and productive in the economic and social sphere. For example, the book for the 4th grade entitled "A conquista da matemática" (Giovanni Júnior, 2018) presents the "Educação Financeira" section, which is presented in five of the nine existing units. The guidelines in the teacher's book is that

In this section, students will get in touch with situations and activities that involve notions of Financial Education. We believe that stimulating reflections about the history of money, the importance of life projects and planning, as well as thinking about the differences between consumption and consumerism, can help them become more reflective and critical citizens and establish a healthier relationship with money. (Giovanni Júnior, 2018, p. XII)

The texts consist of addressing historical aspects of money, the issue of exchange of goods by presenting the monetary standard bills and when discussing the maturity of goods and, as shown in Figure 3, in the presentation of the five "Rs" of the conscious consumption (Rethink, Refuse, Reduce, Reuse, and Recycle).

Figure 3 shows a text on conscious consumption in a 2018 mathematics textbook. 
Figure 3

Text on conscious consumption in a mathematics textbook (Giovanni Júnior, 2018)

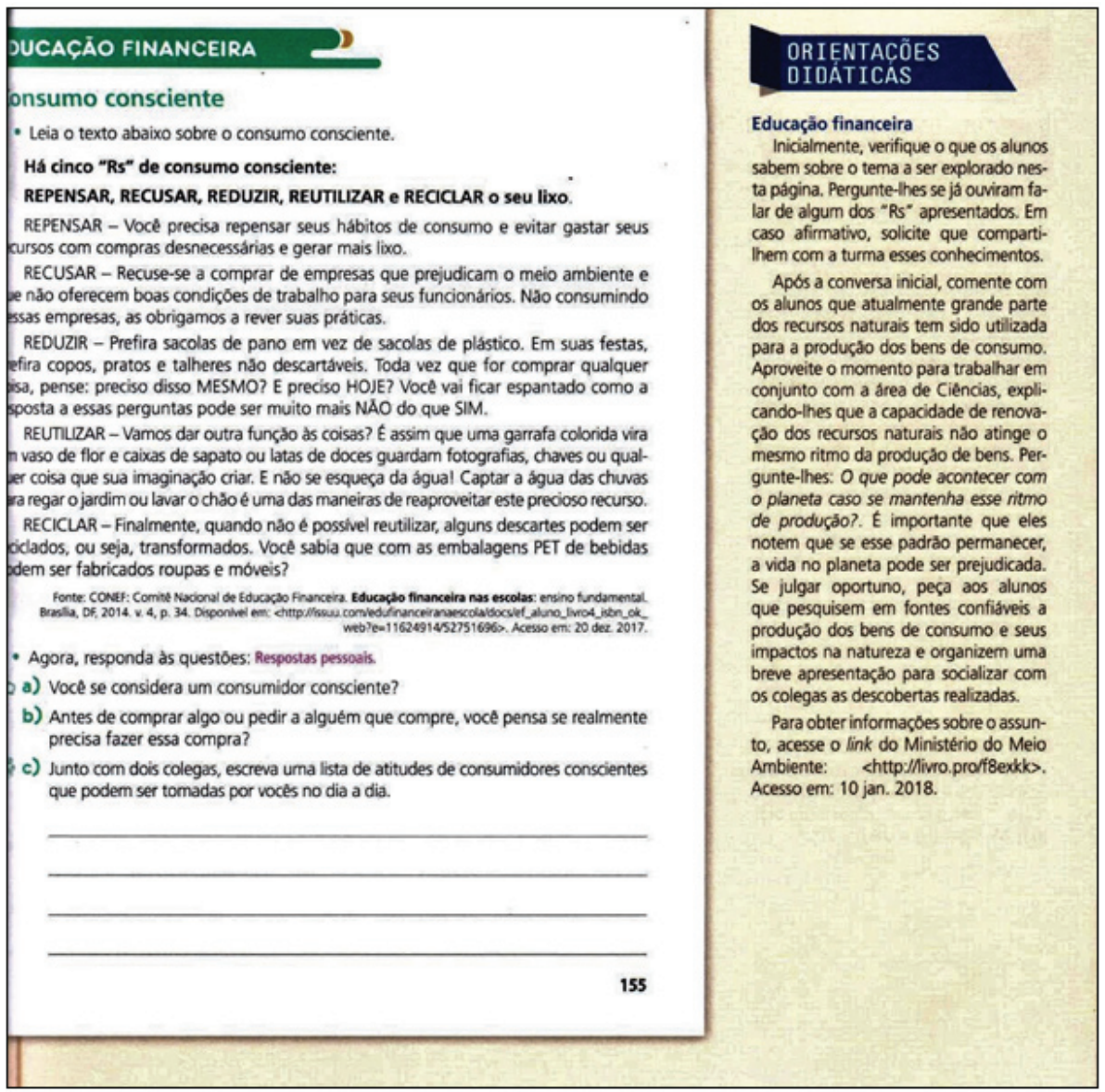

The consumer should therefore no longer be just one who consumes what suits him, or one who simply knows how to exchange money for the merchandise he needs and calculates, based on how much he had and how much he spent, how much is left. Now, he must be the one who actively participates in the economic game, being his own entrepreneur, based on his own practices such as, for example, those that are registered in the 4th grade textbook: rethinking, refusing, reducing, reusing and recycling.

The third precaution concerns not to consider that some hold power while others are subjected to it.

Power must be analysed as something that circulates, or rather, as something that only works in a chain. It is never located here and there, it is never in the hands of 
some, it is never appropriate as a wealth or asset. Power works and is exercised in a network. In its meshes, individuals not only circulate, but are always in a position to exercise that power and to suffer its action; they are never the inert or consented target of power, they are always centres of transmission. In other words, power does not apply to individuals, it passes through them. (Foucault, 2017, p. 284)

This inspires us to consider that power is not located, for example, in the Organisation for Economic Cooperation and Development (OECD), which produced documents advocating a financial education for the population to be inserted in the first years of school life (OECD, 2017), but that there is a network where individuals are centres of transmission and the first effects of power. This inspires us to think about the naturalization of the importance of financial education being present in the mathematics curriculum that is taught at school. It is not something that is imposed by those who hold power, while teachers, researchers and students are subjected to this higher power, they also exercise power while undergoing action, by naturalizing, defending or reframing the insertion of this theme. Which means that they are bodies that sustain it, they are the agents, while being the effects of the power relations that form this event.

The fourth precaution, on the other hand, would be not to start from a supposed centre of power and see how far it extends, but to do an upward analysis, that is, starting from its mechanisms, techniques and tactics.

\begin{abstract}
I believe that the way in which phenomena, techniques and procedures move, expand, change must be analysed; but above all how they are invested and annexed by more global phenomena; as more general powers or economic profits they can be inserted in the game of those technologies of power that are, at the same time, relatively autonomous and infinitesimal. (Foucault, 2017, p. 285)
\end{abstract}

In the case of the object we are dealing with here, it is to problematise the techniques and show how the economic profits or the political utilities of a financial education for the population can be inserted in these techniques. Analysing the textbooks and the theses and dissertations, we realize that this is attached to more global phenomena when constituting a certain type of homo economicus, both the factory and commerce entrepreneur, and the conscious consumer who produces his own satisfaction.

The fifth methodological precaution indicates that, although ideologies may have been produced such as, for example, of education, what is formed at the base "is much less and much more than that. They are real instruments for the formation and accumulation of knowledge" (Foucault, 2017, p. 288). It suggests, then, to move away from the understanding that the indication of a financial education for the classroom is simply a superior imposition of a capitalist ideology, but rather a relationship of power and a confrontation of forces that form and sustain the theme. 


\section{FINAL CONSIDERATIONS}

To intervene extemporaneously means to intervene "[...] against the time, about the time and in favour of a future time" (Nietzsche, 2014, p. 31). Our intervention starts from the present problem, this financial education theme that is linked to the contents of mathematics that is taught in Brazilian schools and questions the conditions of possibility of the event. For this, it was essential to use history and philosophy, especially the concepts related to genealogical writing inspired by Nietzsche and, mainly, by Michel Foucault.

Here we present some of those concepts that inspired our research procedures and analysis of the documentation corpus: Herkunft (provenance) and Entestehung (emergence). This means suspending and opposing Ursprung (origin) research and building a new beginning; considering the body as an interstice, an empty place that sustains and is sustained by events; and relating the entry of forces to the power relations. Along with this, we present the five methodological precautions for the analysis of power that, in short, makes us think of power as something that circulates and that forms mechanisms and tactics of accumulation of knowledge.

Methodologically, to carry out such an analysis, the Common National Curricular Base (BNCC) is considered, as well as the actions of multilateral organisations such as OECD and ENEF, not as the origin of the inclusion of the theme in the curriculum, but as a problematic starting point for the construction a new beginning.

The analysis of current textbooks and other historical moments and of the statements present in the theses and dissertations on the linked theme allows to describe certain economic and social conditions in a discursive, historically, and culturally situated process. The origin constructed indicates a condition of possibility that, since at least the 1940s, school mathematics has encountered: the formation of the homo economicus, either as an entrepreneur in commerce and the factory, or as a consumer who acts "consciously" in his/ her reality, maintaining the good operation of the economy or questioning it critically.

From the five methodological precautions we operated in this work, and of Foucauldian inspiration, we outline: a) that power is not found exclusively in school legislation or curriculum, but also in a dispersion of other practices (school, academic, socioeconomic research); b) that we are interested in the power relations that are engendered in the formation of financial education, more than the intention of seeking the origin of the insertion of the theme in the curriculum; c) that power is not located in an institution such as, for example, the OECD, which would impose something on education from there, but that there is a network where the subjects are agents and effects of the event; d) that the analysis should not start from a supposed centre of power, but from the mechanisms, techniques and tactics that shape the financial education theme; e) and that financial education is not a capitalist ideological imposition, but a result of a confrontation of forces and power relations.

Therefore, what remains for the teacher who teaches mathematics in schools today goes beyond teaching financial mathematics, passing to financial education in a conscientious way. In this research, our goal was to intervene extemporaneously so that 
it is possible for teachers to reflect and problematise their practice in the face of this new role that is attributed to them.

\section{AUTHORSHIP CONTRIBUTION STATEMENT}

J.I.S. collected and selected the sources, treated and analysed the sources selected, elaborated the theoretical-methodological part and the writing of the text. C.R.F. guided and supervised the analysis of the sources, guided the theoretical-methodological elaboration as well as contributed to the complementation of the written text.

\section{DATA AVAILABILITY STATEMENT}

The data that are the basis for the construction of this study are not available yet because they are private documentation for the preparation of ongoing thesis research.

\section{ACKOWLEDGEMENTS}

We are grateful to Capes/Fapesc for granting a doctoral scholarship to the first author, and CNPq for productivity grant to the second author, which made this research possible.

\section{REFERENCES}

Alves, G. M. (2014). As contribuições da Etnomatemática e da perspectiva sociocultural da História da Matemática para a formação da cidadania dos alunos de uma turma do $8^{\circ}$ ano do ensino fundamental por meio do ensino e aprendizagem de conteúdos da Educação Financeira (358 f.). Dissertação de Mestrado Profissional em Educação Matemática, Universidade Federal de Ouro Preto, Ouro Preto, SP, Brasil.

Brasil. (1996). Lei de Diretrizes e Bases da Educação Nacional. Lei número 9394, 20 de dezembro. http://www.planalto.gov.br/ccivil_03/Leis/L9394.htm

Brasil. (1998). Parâmetros Curriculares Nacionais (PCNs). Matemática. Ensino Fundamental. Terceiro e quarto ciclos. http://portal.mec.gov.br/seb/arquivos/pdf/ matematica.pdf

Brasil. (2009). Altera a redação do art. 26 da Lei n. ${ }^{\circ}$ 9.394. Projeto de Lei número 171, 20 de dezembro. https://legis.senado.leg.br/sdleg-getter/documento?dm=3374541\&ts= 1567523766211

Brasil. (2010). Institui a Estratégia Nacional de Educação Financeira - ENEF, dispõe sobre a sua gestão e dá outras providencias. Decreto Federal $n^{\circ}$ 7.397. http://www.planalto. gov.br/ccivil_03/_Ato2007-2010/2010/Decreto/D7397.htm 
Brasil. (2016). Base Nacional Curricular Comum. (2 ${ }^{\mathrm{a}}$ versão). https://undime-sc.org.br/ download/2a-versao-base-nacional-comum-curricular/

Brasil. (2017). Base Nacional Curricular Comum. Educação Infantil e Ensino Fundamental. http://basenacionalcomum.mec.gov.br/abase/

Brasil.(2018). Base Nacional Comum Curricular. Ensino Médio. http://basenacionalcomum. mec.gov.br/wp-content/uploads/2018/06/BNCC_EnsinoMedio_embaixa_site_110518. pdf

Campos, M. B. (2012). Educação financeira na matemática do ensino fundamental: uma análise de produção de significado (179 f.). Dissertação de Mestrado, Curso profissionalizante em Educação Matemática, Universidade Federal de Juiz de Fora, Minas Gerais.

Duarte, C. G. (2009). A "realidade” nas tramas discursivas da educação matemática escolar (198 f.). Tese de Doutorado, Programa de Pós-Graduação em Educação, Universidade do Vale do Rio dos Sinos, São Leopoldo, Rio Grande do Sul.

Foucault, M. (2017). Microfisica do poder. (5 ${ }^{\mathrm{a}}$ ed.). Paz e Terra.

Foucault, M. (2018). Nascimento da Biopolítica. Edições 70.

Giovanni Júnior, J. R. (2018). A conquista da matemática, $4^{\circ}$ ano. (Componente curricular de matemática: Ensino Fundamental, anos iniciais). FTD.

Kern, D. T. B. (2009). Uma reflexão sobre a importância de inclusão de educação financeira na escola pública (200 f.). Dissertação de Mestrado, Ensino de Ciências Exatas, Univates, Lajeado.

Machado, R. (2006). Foucault, a ciência e o saber. ( $3^{\mathrm{a}}$ ed.). Zahar.

Nietzsche, F. (2009). Genealogia da moral. Companhia das Letras.

Nietzsche, F. (2014). Sobre a utilidade e a desvantagem da história para a vida. Hedra.

Euclides, R.; Cecil T.; Mello e Souza. (1940). Curso de Matemática $2^{\circ}$ ano. (8 ed.). Francisco Alves.

Novaes, R. C. N. (2009). Uma abordagem visual para o ensino de Matemática Financeira no Ensino Médio (201 f.). Dissertação de Mestrado, Curso de Ensino de Matemática, Universidade Federal do Rio de Janeiro, Rio de Janeiro.

OCDE. (2017). PISA 2015 results (Volume IV): Students' Financial Literacy. OCDE Publishing.

Oliveira, A. A. (2014). Matemática Financeira: análise de livros didáticos (76 f.). Dissertação de Mestrado, Instituto Nacional de Matemática Pura e Aplicada, Rio de Janeiro.

Reis, S. R. (2013). Matemática financeira na perspectiva da educação matemática crítica (113 f.). Dissertação de Mestrado, Profissional em Educação Matemática, Universidade Federal de Santa Maria, Santa Maria.

Ribeiro, C. E. (2018). Nietzsche, a genealogia, a história: Foucault, a genealogia, os corpos. Cadernos Nietzsche, 39(2), 125-160. https://doi.org/10.1590/2316-82422018v3902cer Roxo, E.; Thiré, C.; Souza, M. (1940). Curso de matemática $2^{a}$ ano. ( $8^{\mathrm{a}}$ ed.). Francisco Alves.

Sangiorgi, O. (1954). Matemática para a Terceira Série Ginasial. (3 ${ }^{\mathrm{a}}$ ed.). Companhia Editora Nacional. 
Schneider, I. J. (2008). Matemática Financeira: um conhecimento importante e necessário para a vida das pessoas (111 f.). Dissertação de Mestrado, Curso de Educação, Universidade de Passo Fundo, Passo Fundo.

Vargas, P. R. R. (2012). Um estudo sobre educação financeira e instituição escolar (121 f.). Tese de Doutorado, Programa de Pós-Graduação em Educação, Universidade do Vale dos Sinos, São Leopoldo. 